\title{
EVALUASI PRODUKSI AYAM BROILER YANG DIPELIHARA DENGAN SISTEM CLOSED HOUSE
}

\author{
SUASTA, I.M., I G. MAHARDIKA, DAN I W. SUDIASTRA \\ Fakultas Peternakan, Universitas Udayana \\ e-mail: madesuasta@unud.ac.id
}

\begin{abstract}
ABSTRAK
Penelitian telah dilakukan untuk mengetahui tentang performa produksi dan analisis usaha ayam broiler yang dipelihara pada kandang closed house. Penelitian dilakukan pada kandang system closed house dengan kapasitas 11.00o ekor. Variabel yang diamati adalah pertumbuhan ayam, konsumsi pakan, efisiensi penggunaan pakan, deplesi serta aspek ekonomi. Hasil penelitian menunjukan bahwa berat badan rata-rata pada umur 30 hari adalah 1620 g/ekor, deplesi sebesar 2,13\%, FCR sebesar 1,56 dan Indek performa 339,2. Secara ekonomis pemeliharaan ayam broiler dengan sistem close house menguntungkan, yang ditunjukan oleh pendapatan bersih Rp. 2.781/ekor dan R/C rasio sebesar 1,10. Break Event Point (BEP) harga usaha pemeliharaan ayam broiler adalah: Rp. 16.032/ $\mathrm{kg}$.
\end{abstract}

Kata kunci: ayam broiler, produktivitas, closed house

\section{PRODUCTIVE EVALUATION OF BROILER CHIKEN IN CLOSED HOUSE SYSTEM}

\begin{abstract}
ABSRACT
Research has been conducted to find out about the performance of the production and analysis of a broiler chicken business in be kept in closed house system. The research done in a cage with closed house system with a capacity of 11,00o birds. The observed variables are the growth of the chicken feed consumption, the efficiency of feed composition (FCR), depletion and economic aspects. Results of the study showed that the average weight at the age of 30 days is $1620 \mathrm{~g} / \mathrm{bird}$, depletion 2.13\%, the FCR 1.56 and Index performance was 339.2. net income Rp. 2.781/tail and R/C ratio of 1.10. Break Event Point (BEP) was: Rp. 16.032/kg.
\end{abstract}

Key words: broiler chikens, produkdivity, closed house

\section{PENDAHULUAN}

Ayam broiler merupakan salah satu ras ternak unggas yang cukup populer dan banyak dipelihara oleh peternak di Bali sebagai penghasil daging karena memiliki keunggulan laju pertumbuhan yang cepat dan kemampuan mengkonversi pakan yang efisien dibanding ayam ras lainnya. Ini menjadi alasan mengapa banyak peternak lebih memilih memelihara ayam broiler sebagai ayam penghasil daging karena waktu pemeliharaan yang singkat, sehingga keuntungan yang didapat lebih tinggi. Ayam broiler merupakan unggas yang efisien dalam menghasilkan daging. Namun faktor biaya produksi usaha ayam pedaging ini relatif tinggi yakni hampir $80 \%$ dari total penerimaan peternak. Selain itu, kapasitas pemeliharaan ditambah harga daging yang fluktuatif merupakan kendala dalam memperoleh keuntungan yang maksimal (Abidin,
2002). Suatu usaha peternakan ayam broiler baik yang bersifat mandiri maupun kemitraan yang menggunakan kandang tipe closed house dan opened house system seluruhnya berorientasi pada pencapaian keuntungan. Untuk itu diperlukan suatu perhitungan dan analisa ekonomi yang tepat.

Kandang closed house merupakan kandang sistem tertutup yang dapat menjamin keamanan biologis seperti menghindari kontak dengan mahluk hidup lain yang dapat menyebabkan penyakit dan stress pada ternak. Kandang closed house menggunakan pengaturan ventilasi yang baik sehingga suhu di dalam kandang menjadi lebih rendah dibanding suhu diluar kandang, kelembaban, kecepatan angin dan cahaya yang masuk kedalam kandang dapat diatur secara optimal, sehingga tercipta suatu kondisi yang nyaman bagi ayam, hal ini dapat menghindari stress pada ayam yang berlebihan. Prinsip dari kandang sistem tertutup 
yaitu menyediakan udara yang sehat untuk ternak, iklim yang nyaman, dan mengurangi kontak dengan manusia agar ternak tidak stress. Kandang dibangun dengan sistem ventilasi yang baik agar tersedianya udara yang sehat dan pergantian udara yang lancar. Dengan demikian akan tercipta udara kandang yang banyak mengandung oksigen dan gas-gas berbahaya seperti amoniak dan karbondioksida dikeluarkan sesegera mungkin dari kandang. Menyediakan kondisi iklim yang nyaman dengan cara dibuat kondisi angin berhembus dengan alat kipas angin dan pada daerah yang terlalu panas menggunakan sistem pendingin dengan mengalirkan air pada alat berupa cooling pad, dan cooling net. Dengan iklim yang nyaman maka panas yang dihasilkan dari tubuh ternak dapat dikeluarkan dari kandang dan ternak terhindar panas yang berasal dari lingkungan luar. Menekan seminimal mungkin tingkat stress pada ternak dengan cara mengurangi kontak dengan manusia. Maka dibuatlah dengan sistem pemberian pakan dan minum otomatis pada kandang dengan sistem tertutup.

Mortalitas, FCR (feed conversion ratio), pengaruh iklim dan kenyamanan kandang, adalah beberapa faktor yang dapat mempengaruhi performa ayam broiler. Sehingga dirasa perlu untuk melakukan pengukuran dari faktor-faktor tersebut untuk mengetahui performa produksi ayam broiler serta dilakukan analisis untuk mengetahui pendapatan usaha, $\mathrm{R} / \mathrm{C}$ rasio dari usaha pemeliharaan ayam broiler yang dipelihara dalam kandang closed house.

\section{MATERI DAN METODE}

\section{Ayam}

Penelitian ini dilakukan pada peternakan ayam sistem closed house dengan kapasitas 11.000 ekor strain Lohman MB 202. Ayam dipelihara dari umur 1 hari sampai umur 30 hari. Sampel ayam yang diukur performanya adalah 50 ekor yang akan diambil secara acak.

\section{Kandang dan Perlengkapannya}

Ayam dipelihara pada kandang closed house. Lantai dasar kandang dibuat dengan bahan semen dan pada tingkat pertama menggunakan slat kayu dan diberi terpal pada bagian permukaannya. Pada lantai dasar dan tingkat pertama digunakan sekam sebagai alas. Dinding kandang terbuat dari terpal. Atap kandang terbuat dari bahan asbes dan plafon kandang terbuat dari bahan terpal. Perlengkapan kandang terdiri dari kipas (exhaust fan) dan cooling fan. Perlengkapan kandang terdiri dari pemanas atau brooder, tempat pakan DOC, tempat pakan ayam dewasa, tempat minum otomatis (nipple) dan generator set (genset).

\section{Alat Penelitian}

Peralatan yang digunakan dalam penelitian ini adalah timbangan untuk menimbang berat badan ayam, dan berat ransum. Termometer untuk mengukur suhu udara di dalam dan diluar kandang.

\section{Ransum dan Air Minum}

Ransum yang diberikan yaitu ransum komersial, terdapat tiga jenis ransum yang diberikan yaitu ransum pre-starter (umur 1 - 14 hari), ransum fase starter (umur 14 - 21 hari), dan ransum fase finisher (umur 21 hari - panen). Kandungan masing-masing nutrisi ransum tercantum pada Tabel 3.1. Air minum selama penelitian ini yaitu diberikan air yang berasal dari sumur bor yang dialirkan ke dalam kandang secara otomatis.

\section{Variabel}

Variabel yang diamati yaitu deplesi, konsumsi ransum, pertambahan bobot badan, feed conversion ratio (FCR), bobot badan akhir, deplesi, indeks performa (IP), dan aspek ekonomi meliputi: biaya investasi, biaya produksi, penerimaan usaha, pendapatan usaha, R/C Ratio, Break Even Point (BEP).

\section{Analisis Data}

Data yang diperoleh dianalisis secara deskriptif. Disamping itu hasil-hasil pengukuran akan dibandingakan dengan standar performa ayam broiler menurut standar dari Jafa Comfeed. Analisis ekonomi meliputi analisis total biaya produksi, pendapatan, penerimaan, BEP dan RC Ratio

\section{HASIL DAN PEMBAHASAN}

\section{Berat Badan}

Rataan berat badan awal ayam broiler umur satu hari (DOC) adalah $40 \mathrm{~g}$ /ekor, sedangkan rataan berat badan akhir ayam broiler yang dipelihara selama 30 hari dengan sistem closed house adalah 1620 g/ekor. Dengan demikian kenaikan berat badan ayam tersebut selama 30 hari adalah $1580 \mathrm{~g}$ /ekor atau rata-rata 52,67 g/ekor/hari. Kenaikan berat badan ini sudah memenuhi standar pertumbuhan ayam broiler strain Lohman MB 202. Hal ini menunjukkan bahwa manajemen pemeliharaan ayam broiler dengan system closed house ini sudah sesuai dengan standar pemeliharaan. Susana et al. (2018) yang meneliti penggantian tepung ikan dengan limbah wine mendapatkan bahwa berat badan akhir ayam broiler antara 1,235 - 1,460 kg. dengan kenaikan berat badan rata-rata sebesar 1,028 - 1,273 kg. Sedangkan penelitian Reyes et al. (2018) yang memberikan ransum dengan kandungan protein 20,7\% dan ME. $2900 \mathrm{~K} . \mathrm{kal} / \mathrm{kg}$ mendapatkan bahwa berat 
badan akhir ayam broiler umur 28 hari adalah 1,157 $1,267 \mathrm{~kg}$. Sudarman et al. (2012) mendapatkan bahwa performan ayam broiler yang diberikan ektrak daun beluntas pada air minumnya mengalami peningkatan secara signifikan. Kurva kenaikan berat badan ayam selama 30 hari ditampilkan dalam Gambar 1.

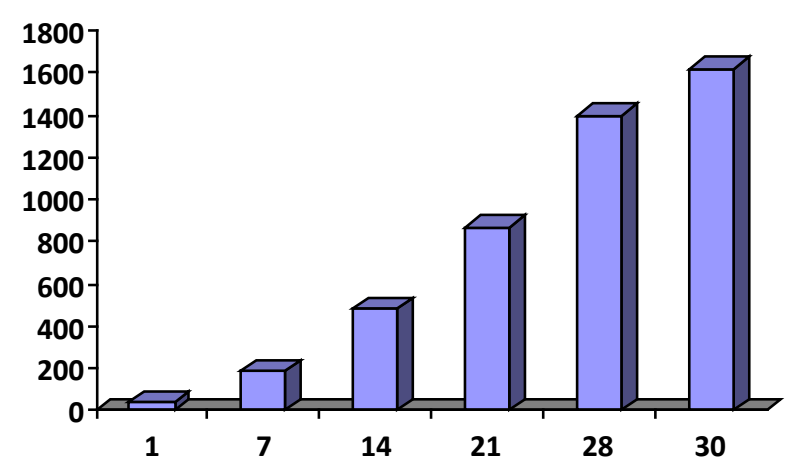

Gambar 1. Perkembangan berat ayam broiler yang dipelihara secara closed house selama 30 hari.

\section{Performa Produksi}

Rata-rata konsumsi pakan aym broiler selam 30 hari adalah $2474 \mathrm{~g}$ /ekor. Hasil ini sesuai dengan standar pemeliharaan ayan broiler yaitu sebesar 2450 g/ekor. Tabel 1. menunjukkan perkembangan ayam broiler yang dipelihara selama 30 dengan sistem closed house

Tabel 1. Perkembangan ayam broiler yang dipelihara selama 30 hari dengan system closed house

\begin{tabular}{cccccc}
\hline $\begin{array}{c}\text { Umur } \\
\text { (hari) }\end{array}$ & $\begin{array}{c}\text { Berat badan } \\
(\mathrm{g})\end{array}$ & $\begin{array}{c}\text { Kenaikan } \\
\text { berat badan } \\
(\mathrm{g})\end{array}$ & $\begin{array}{c}\text { Konsumsi } \\
(\mathrm{g})\end{array}$ & FCR & $\begin{array}{c}\text { Deplesi } \\
(\%)\end{array}$ \\
\hline 1 & 40 & 0 & - & - & - \\
7 & 185 & 145 & 183 & 1,26 & 0,78 \\
14 & 480 & 440 & 570 & 1,29 & 1,37 \\
21 & 870 & 830 & 1245 & 1,50 & 1,73 \\
28 & 1400 & 1360 & 2094 & 1,54 & 2,00 \\
30 & 1620 & 1580 & 2474 & 1,56 & 2,13 \\
\hline
\end{tabular}

Konsumsi pakan ayam broler pada penelitian ini didapatkan adalah $2474 \mathrm{~kg}$ selama 30 hari, dengan konversi pakan sebesar 1,56 . Hasil ini menunjukan bahwa system close house memberikan performa produksi yang baik. Hasil penelitian Reyes et al. (2018) mendapatkan bahwa pemeliharaan ayam broiler selama 28 hari mendapatkan bahwa berat badan akhir, konsumsi ransum dan FCR berturut-turut 1,267 kg; 1,9 $\mathrm{kg}$ dan 1,69. Di ain pihak Astuti et al. (2016) mendapatkan bahwa ayan broiler yang dipelihara dengan sistem opened house yang diberikan ransum mengandung tepung buah naga terfermentasi mendapatkan bahwa FCR ayam tersebut adalah: 1,99-2,07.

Lebih baiknya performan ayam broiler yang dipelihara pada kandang sistem closed house disebabkan karena kondisi iklim mikro pada kandang closed house lebih baik daripada kandang open house. Penelitian Yani et al. (2014) mendapatkan bahwa temperatur udara dalam kandang closed hause adalah $26-28^{\circ} \mathrm{C}$ dengn deviasi temperatur yang sagat rendah. Kondisi ini akan meningkatkan kenyamanan ayam sehingga dapat berproduksi secara optimal.

Berdasarkan data pada Tabel 1 di atas dapat dihitung Indek Performa (IP) pemeliharaan ayam broiler yaitu 339,2. Nilai ini termasuk dalam katagori baik. Medion (2010) menyatakan bahwa IP yang baik untuk pemeliharaan ayam broiler adalah di atas 300, sedangkan katagori sangat baik bila di atas 350. Hasil peneltin ini lebih baik dari yang didapatkan oleh Sudarman et al. (2012) yang mendapatkan bahwa ayam broiler yang diberikan 10\% ektrak daun beluntas pada air minumnya, berat badan akhir dan FCRnya masingmasing $850 \mathrm{~g}$ dan 1,95 .

\section{Perhitungan Aspek Ekonomi}

Biaya produksi yang dikeluarkan selama 30 hari pemeliharaan 12.000 ekor ayam broiler sebesar Rp. 302.305.000, yang terdiri dari biaya pembelian bibit, biaya pakan, baaya obat-obatan, gas tenaga kerja, listrik, air, pembelian sekam dan penyusutan kandang serta alat-alat. Rincian biaya pemeliharaan ditampilkan pada Tabel 2, sedangkan rincian penerimaan ditampilkan pada Tabel 3 .

Berdasarkan hasil perhitungan tersebut, keuntungan bersih dari pemeliharaan ayam broiler dengan sistem closed house selama 30 hari adalah Rp. 33.380.111,-Bila dihitung berdasarkan penerimaan bersih setiap ekornya adalah Rp. 2.781/ekor.

Berdasarkan atas hasil perhitungan pendapatan dan biaya, maka $\mathrm{R} / \mathrm{C}$ rasio dari pemeliharaan ayam broiler ini didapatkan 1,10. Ini artinya usaha pemeliharaan ini memberikan keuntungan yang layak.

Tabel 2. Rincian biaya pemeliharaan 12.000 ekor ayam broiler dengan sistem closed house

Komponen Biaya

Total Biaya $(\mathrm{Rp})$

Biaya Tidak Tetap

- DOC

- Pakan

- Obat-obatan

- Gas

- Gaji karyawan

- Listrik

- Sekam

- Biaya panen

Sub Total

74.280.000,

227.025.000,-

1.000.000,

1.620 .000 ,-

5.200 .000 ,

5.500 .000 ,-

3.850 .000

550.000 ,-

319.025.000,-

Biaya Tetap

- Penyusutan Kandang 3.300.000,-

- Penyusutan alat-alat $\quad 1.500 .000$,-

Sub Total

4.800.000,-

Total Biaya 
Tabel 3. Rincian pendapatan pemeliharaan ayam boiler

\begin{tabular}{lc}
\hline \multicolumn{1}{c}{ Komponen Pendapatan } & Total Pendapatan (Rp) \\
\hline Penjualan Ayam & $343.056 .975,-$ \\
Penjualan sekam & $3.600 .000,-$ \\
Penjualan kampil & 890.640 - $^{-}$ \\
Bonus & \\
$\quad$ - FCR & $3.863 .000,-$ \\
$\quad$ - Mortality & $1.931 .500,-$ \\
$\quad$ - Efisiensi & $3.863 .000,-$ \\
Total Penerimaan & $357.205 .111,-$ \\
Pendapatan Bersih & $33.380 .111,-$ \\
\hline
\end{tabular}

\section{SIMPULAN}

Berdasarkan hasil penelitian yang diperoleh maka dapat disimpulan bahwa (1) performa ayam broiler yang dipelihara dengan sistem closed house termasuk dalam katagori baik yang ditunjukkan dengan berat badan rata-rata pada umur 30 hari adalah $1620 \mathrm{~g}$ /ekor, deplesi sebesar 2,13\%, FCR sebesar 1,56 dan indeks performa 339,2. (2) Secara ekonomis pemeliharaan ayam broiler dengan sistem closed house menguntungkan, yang ditunjukkan oleh pendapatan bersih Rp. 2.781/ekor dan $\mathrm{R} / \mathrm{C}$ rasio sebesar 1,10. (3) break event point (BEP) harga usaha pemeliharaan ayam broiler adalah: Rp. $16.032 / \mathrm{kg}$.

\section{DAFTAR PUSTAKA}

Abidin, Z. 2002. Meningkatkan produktivitas ayam ras pedaging. Agromedia Pustaka. Jakarta.

Astuti, I., I M. Mastika dan G.A.M.K. Dewi (2016). Performa ayam broiler yang diberikan ransum mengandung tepung kult buah naga tanpa dan dengan Aspergilus niger terfermentasi. Majalah Ilmuah Peternakan: 19 (2): $75-70$.

Medion info (2010). Berhasil tidaknya pemeliharaan ayam broiler. http://info.medion.co.id/index.php/artikel broiler.

Reyes. F.C.C., A.T.A. Aguirre, E.M. Agbisit. Jr., F.E. Merca, G.L. Manulat, and A.A. Angeles (2018). Growth performance and carcass characteristics of broiler chicken fed akasya [(Samanea Saman (Jacq.) Merr.] pod meal. Media Peternakan (Journal of Animal Science Tecnologi): 41(1): $46-52$.

Sudarman, A., Sumiati and R. Kaniadewi (2012). Performance of broiler chickens offered drinking water contained extracted beluntas (Pluchea indica L.) leaf and sugar cane. Journal of Animal Science Tecnologi 35(2):117 - 122.

Susana, W., I.M. Nuryasa dan N. W. Siti (2018). Pengaruh penggantian teung ikan dengan limbah wine anggur terfermentasi terhadap performan ayam broiler. Majalah Ilmiah Peternakan. 21(1): 29 - 31 .

Yani. A., H. Suhardiyanto, Erizal and B.P. Purwanto. (2014). Analysis of air temperature distribution in a closed house for broiler in wet tropical climate. Media Peternakan (Journal of Animal Science Technologi): 37(2): $87-100$. 